\title{
Prospects for environmentally safe mechanical biological treatment of municipal solid waste in Ukraine
}

\author{
Yuliia Makovetska ${ }^{1, *}$, Tetiana Omelianenko ${ }^{1}$, and Alla Omelchenko ${ }^{1}$ \\ ${ }^{1}$ Public Institution "Institute of Environmental Economics and Sustainable Development of the National \\ Academy of Sciences of Ukraine", 60 Blvd. Tarasa Shevchenko, 01032 Kyiv, Ukraine
}

\begin{abstract}
Improving waste management is currently one of the priorities for Ukraine in the environmental safety. EU experience in the use of mechanical biological waste treatment technologies should be applied now in connection with the development and implementation of Regional Waste Management Plans in Ukrainian regions. The aim of the paper is to analyse the benefits and the preconditions of using mechanical biological waste treatment technologies in Ukraine, as well as barriers that may hinder the construction of mechanical biological waste treatment plants. The analysis of the eight drafts of the Regional Waste Management Plans showed that the mechanical biological waste treatment technologies market is free in Ukraine and the best option for the regions where there are cement plants operating is production of solid recovered fuel. Such types of projects could be affordable for Ukrainians with the cost recovery period more than 8 years. On the other hand there are significant obstacles of economic, organizational and technological nature to their immediate implementation i.e. low rates on waste disposal tax, partly compliance on air emissions monitoring system, absence of necessary standards etc. The priority actions to speed up mechanical biological waste treatment technologies implementation have been defined.
\end{abstract}

\section{Introduction}

The level of environmental safety of Ukraine is influenced by the inherited structure of the economy with a dominant share of resource- and energy-intensive industries; wear and tear of fixed assets of industrial and transport infrastructure; the existing system of public administration in environmental protection. The environmental situation as a whole continues to deteriorate [1].

Both in Europe and around the world, the problem of waste is now emerging as one of the determining factors of environmental and social safety. This fully applies to Ukraine which faces a number of pressing challenges in waste management. According to the dates of the Ministry for Communities and Territories Development, in 2020, Ukraine generated more than 54 million $\mathrm{m}^{3}$ of municipal solid waste, or more than 15 million tons [2] and $93.7 \%$ of them are disposed of on landfills and dumpsites.

\footnotetext{
*Corresponding author: yulia_2505@ukr.net
} 
There are 6,000 landfills and dumpsites with a total area of almost 9,000 hectares [2]. Most of them do not meet environmental standards and requirements. Waste management reforms are progressing very slowly in Ukraine. The Law of Ukraine "On waste" (1998) does not meet modern requirements. They have been talking about new legislation since 2014, when Ukraine signed the Association Agreements Ukraine-EU. However, the new law has not yet been adopted.

The National Waste Management Strategy in Ukraine until 2030 and National Waste Management Plan until 2030 was adopted in 2017 and 2019 respectively. After that the Regional Waste Management Plans began to be developed in the regions of Ukraine. One of the solutions proposed by Regional Waste Management Plans is the construction of mechanical biological waste treatment plants. Mechanical biological waste treatment plants prepare municipal solid waste for recovery and disposal operations, including separation and stabilization of the easily biodegradable fraction and also limitation of the landfilling of biodegradable waste in landfills. According to the market study the mechanical biological waste treatment technologies market will continue to grow rapidly. In the past 5 years, an average of about 25 new mechanical biological waste treatment plants were constructed annually in Europe. This allows treating about 2.2 million tons of waste annually. In early 2017, there are about 570 active mechanical biological waste treatment plants with a treatment capacity of 55 million tons was in Europe [3].

Thus, the authors of the paper are taking into consideration prospects and opportunities for the development of a mechanical biological waste treatment plants in Ukraine. Analyse of the drafts of the first-ever Regional Waste Management Plans in regions of Ukraine are presented.

\section{Mechanical biological techniques}

After the adoption of the requirements of the Directive 1999/31/EU on the landfill of waste, namely, regarding the removal of biodegradable waste from landfills, mechanical biological waste treatment technology has begun to develop rapidly. The possibility of using high calorific fractions as fuel after such treatment also played a significant role in increasing the number of mechanical biological waste treatment plants. The shares of the output fractions, especially of the recyclables and alternative fuel determine the overall efficiency of mechanical biological waste treatment plant [4].

Mechanical biological technology can increase the useful life of the disposal site, reduce the amount of waste inflow and prevent organic fraction degradation which is treated before landfilling using biological technologies. Mechanical biological technology is able to reduce the environmental impacts due to leachate and landfill gas emissions reducing $[5,6]$.

The mechanical biological technologies cover a wide variety of processes, ordinarily combining some form of mechanical sorting or physical treatment with biological treatment. There are practically three main types of mechanical biological waste treatment plants structure. They are:

- Bio-stabilisation. It implies extraction of recyclable materials with aerobic biostabilisation of organic waste components before landfilling;

- Bio-drying. Such plants provide production of a solid recovered fuel through short and intensive aerobic treatment of residual waste aimed at decreasing the moisture content. Mechanical sorting and extraction of recyclable and inert materials also take place;

- Energy recovery. It implies extraction of recyclable materials, separation of a refuse derived fuel for next thermal treatment in another installations and aerobic/anaerobic treatment of a biodegradable fraction. The outputs after aerobic/anaerobic treatment can be landfilled or if possible used [7]. 
As usual on mechanical biological waste treatment plants the first step is to extract recyclables. Depending on the input municipal solid waste it is possible to receive up to $10 \%$ of recyclables. Other outputs depend on the types of mechanical biological waste treatment plants (Fig. 1).

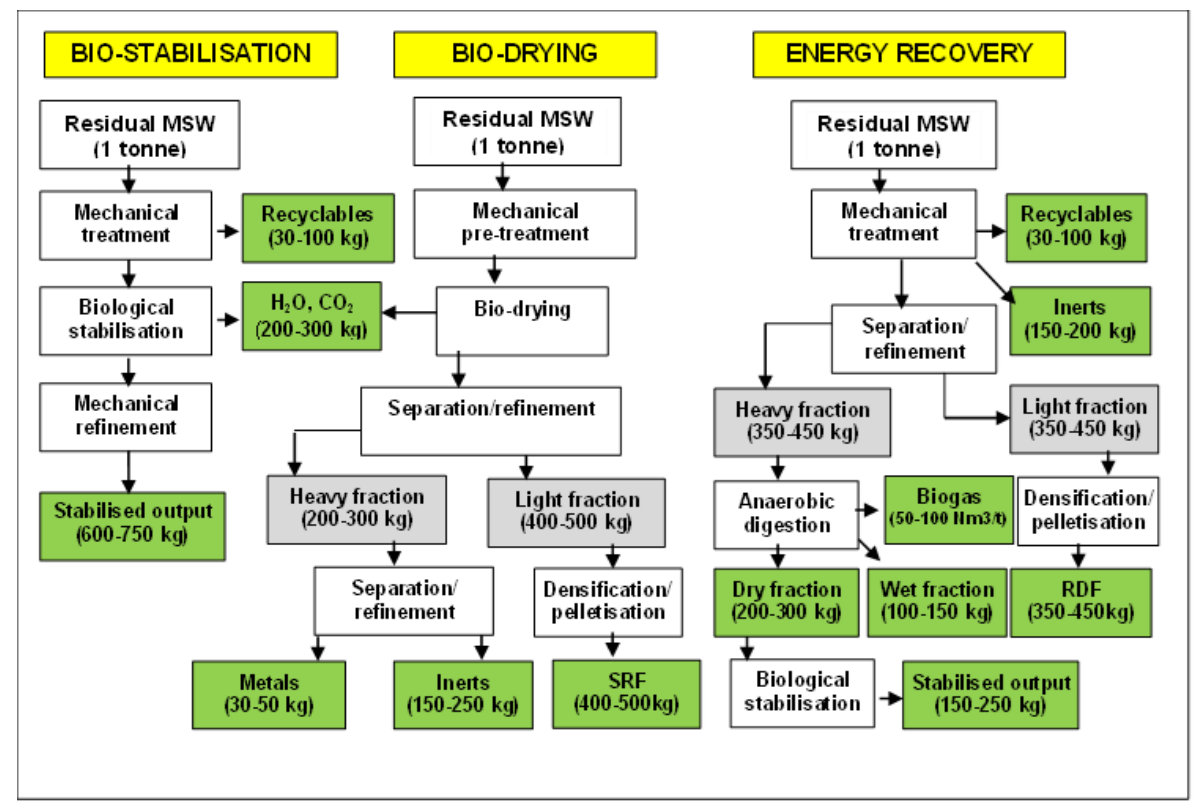

Fig. 1. Mass balance for different configurations of MBT facilities [7].

There are basically two types of energy rich outputs produced at mechanical biological waste treatment facilities:

- separated paper, plastics, wood and some textiles etc., often referred to as refuse derived fuel (RDF), which has a calorific value often ranging between $12-16 \mathrm{MJ} / \mathrm{kg}$;

- residual waste dried through a quick aerobic treatment (bio-drying), from which low calorific value components and inert waste has been separated, often referred to as solid recovered fuel (SRF), which has a calorific value often ranging between 14-18 MJ/kg [7].

Solid recovered fuel is quality fuel than refuse derived fuel and there are corresponding requirements to it. There is a standard EN 15359:2011. Solid recovered fuels. Specifications and classes for production. Standard covers all types of solid recovered fuel. According to the standard solid recovered fuel is divided into 5 classes depending on the mean value for net calorific value; the mean value for chlorine content; and the median and 80th percentile values for mercury content (Table 1).

Table 1. Classification system for solid recovered fuels (EN 15359:2011).

\begin{tabular}{|c|c|c|c|c|c|c|c|}
\hline $\begin{array}{c}\text { Classification } \\
\text { characteristic }\end{array}$ & $\begin{array}{c}\text { Statistical } \\
\text { measure }\end{array}$ & Unit & \multicolumn{5}{|c|}{ Classes } \\
\cline { 4 - 8 } & & $\mathbf{1}$ & $\mathbf{2}$ & $\mathbf{3}$ & $\mathbf{4}$ & $\mathbf{5}$ \\
\hline $\begin{array}{c}\text { Net calorific } \\
\text { value (NCV) }\end{array}$ & Mean & $\mathrm{MJ} / \mathrm{kg}$ & $\geq 25$ & $\geq 20$ & $\geq 15$ & $\geq 10$ & $\geq 3$ \\
\hline Chlorine (Cl) & Mean & $\%$ & $\leq 0,2$ & $\leq 0,6$ & $\leq 1,0$ & $\leq 1,5$ & $\leq 3$ \\
\hline \multirow{2}{*}{ Mercury $(\mathrm{Hg})$} & Median & $\mathrm{mg} / \mathrm{MJ}$ & $\leq 0,02$ & $\leq 0,03$ & $\leq 0,08$ & $\leq 0,15$ & $\leq 0,50$ \\
\cline { 2 - 8 } & $\begin{array}{c}80 \mathrm{th} \\
\text { percentile }\end{array}$ & $\mathrm{mg} / \mathrm{MJ}$ & $\leq 0,04$ & $\leq 0,06$ & $\leq 0,16$ & $\leq 0,30$ & $\leq 1,00$ \\
\hline
\end{tabular}


More potentially better sales will be solid recovered fuel of 3-d class and above.

It should be mentioned that in Ukraine standard EN 15359:2011 adopted as a National standard by the method of "confirmation" - recognition of that the international standard has the status of a national one.

The investment costs for mechanical biological waste treatment facilities vary depending on size, configuration and local factors. The operation and maintenance (O\&M) costs vary according to configuration and related level of complexity of the facility. An indication of the specific investment and O\&M cost ranges and total treatment costs in relation to the input capacity for the three mechanical biological waste treatment facility types discussed above, and some other waste treatment facility types for comparison, are given in the table below (Table 2) [7].

Table 2. Investment and operation costs for different mechanical biological waste treatment facilities.

\begin{tabular}{|l|r|c|c|}
\hline \multicolumn{1}{|c|}{ Type } & $\begin{array}{c}\text { Investment cost } \\
(\boldsymbol{\epsilon} / \mathbf{t} / \mathbf{y r})\end{array}$ & $\begin{array}{c}\text { O\&M cost } \\
(\boldsymbol{\epsilon} / \mathbf{t})\end{array}$ & Total cost $(\boldsymbol{\epsilon} / \mathbf{t})$ \\
\hline MBT - Bio-stabilisation & $100-200$ & $10-25$ & $20-40^{1}$ \\
\hline MBT - Bio-drying & $200-350$ & $20-35$ & $40-70^{1}$ \\
\hline MBT - Energy recovery & $250-450$ & $25-45$ & $60-90^{1}$ \\
\hline
\end{tabular}

${ }^{1}$ Excluding handling costs for RDF/SRF

The key benefits of mechanical biological waste treatment plants are that it can be configured to achieve several different aims. In line with the EU Landfill Directive and in order to achieve certain recycling targets, typical aims of mechanical biological waste treatment plants include:

- the pre-treatment of waste prior to disposal on landfill;

- diversion of non-biodegradable and biodegradable municipal solid waste going to landfill through the mechanical sorting of municipal solid waste into materials for recycling and/or energy recovery, such as refuse derived fuel or solid recovered fuel;

- diversion of biodegradable municipal solid waste going to landfill by stabilisation of municipal solid waste into a compost-like-output for use as landfill cover material or in the rehabilitation of landfills and dumpsites; and

- drying materials to produce a high calorific fraction for use as refuse derived fuel / solid recovered fuel.

On the other hand, there are some caveats to use mechanical biological techniques:

- limited/restricted markets for potential outputs;

- potentially additional high costs for handling of outputs;

- quite high area requirements, especially for aerobic treatment type mechanical biological waste treatment plants; and

- difficult to reduce/handle volatile emissions/odours [4, 7].

\section{Results and discussion}

By signing the Association Agreement with the EU in 2014, Ukraine has chosen the European path of the development, in connection with which the waste management system needs to be significantly modified taking into account the relevant guidelines and policies. Accordingly, one of the tasks of environmental modernization in this area is to create a modern waste management infrastructure.

Ukraine generates annually more than 10 million tons municipal solid waste. Almost $79 \%$ of the population is covered by municipal solid waste collection services. Separate 
collection of municipal solid waste is being implemented slowly. Separate bio-waste collection and home composting are not very widespread in Ukraine [2].

Due to the low level of infrastructure only $4-8 \%$ of municipal solid waste was recovered annually. The main option for municipal solid waste treatment is disposal at landfills and dumpsites, which in most cases does not meet environmental safety requirements. The legal prohibition disposal of un-treated municipal solid waste is not enforced.

This indicates the urgent need for improvement of solid waste management, the scale of which in the financial and economic constraints in the country raises the issue of setting priorities that should be based on the criteria of environmental safety and resource efficiency of solutions $[8,9]$.

The adoption of the National Strategy and National Waste Management Plan until 2030 has set the regions the task of developing Regional Waste Management Plans. Relevant work has begun in almost all regions of Ukraine.

The Order of the Ministry of Environment of Ukraine №142 of April 12, 2019 approved the "Methodological recommendations for the development of Regional Waste Management Plans". The methodological recommendations contain the recommended structure of the Regional Waste Management Plan, instructions on how to fill in each section, a list and sources of necessary information, etc. In general, the Methodological recommendations fully cover the entire process of preparation of the plan, including the need for a Strategic Environmental Assessment.

As of the beginning of 2021, eight regions of Ukraine (of 24) have been made public drafts of the Regional Waste Management Plan and had Strategic Environmental Assessment. Due to a legislative gap, none Regional Waste Management Plans can be approved.

The analysis of options for the development of municipal solid waste treatment infrastructure which are presented in eight Regional Waste Management Plans showed that the priority is to consolidate the disposal system, which is quite logical given the excessive number of disposal sites most of that are environmentally dangerous (at least 90\%).

Among other treatment technologies considered Regional Waste Management Plans are sorting of valuable components of municipal solid waste; aerobic biological treatment (composting) of food and garden waste; and mechanical-biological treatment of waste with biogas and energy production (anaerobic digestion of organic fraction of municipal solid waste). Waste incineration was considered in a single case - in one Regional Waste Management Plan (Dnipropetrovsk region) and alternative scenario for incineration plant is mechanical biological waste treatment plant.

This corresponds to the conclusions of the experts of the Project "Technology Needs Assessment" -that implemented under the Strategic Technology Transfer Program. The Project is designed to help developing countries carry out a Technology Needs Assessment for the United Nations Framework Convention on Climate Change.

In general, almost each of the eight regions (except Chernihivska) planned of one mechanical biological waste treatment plant for mixed municipal solid waste. One region (Dnipropetrovska - one of the most populated) planned two plants with the possibility to increase their number if necessary. The results of the analysis are presented in Table 3 [1016].

Summarising mentioned above most of expectations in Ukraine is oriented on refuse derived fuel production but without further clear understanding of its using, or on solid recovered fuel production for cement industry. Now only several from eight cement plants in Ukraine have clear understanding on it re-equipment for solid recovered fuel using and appropriate costs estimations. Also one of the main challenges is a quite low gate fees and as well as waste disposal tax rates which does not stimulate introduction of any other than landfilling technologies. 
Table 3. Analysis of the drafts of the several Regional Waste Management Plans concerning construction mechanical biological waste treatment plants.

\begin{tabular}{|c|c|c|c|c|c|c|}
\hline \multirow{2}{*}{$\begin{array}{l}\text { Regions/ } \\
\text { Location }\end{array}$} & \multirow{2}{*}{$\begin{array}{c}\text { Capacity, } \\
\text { tpa }\end{array}$} & \multicolumn{4}{|c|}{ Characteristics of planned MBT facilities* } & \multirow[t]{2}{*}{ Notes } \\
\hline & & $\begin{array}{c}\text { Total } \\
\text { investments, } \\
\text { mln EUR }\end{array}$ & $\begin{array}{r}\text { CAPEX, } \\
\text { EUR/t }\end{array}$ & $\begin{array}{l}\text { OPEX, } \\
\text { EUR/t }\end{array}$ & $\begin{array}{c}\text { Calculated } \\
\text { gate fee, } \\
\text { EUR/t }\end{array}$ & \\
\hline $\begin{array}{l}\text { Vinnytska/ } \\
\text { v. Ludavka }\end{array}$ & 160,000 & 15.0 & 94 & $6.7-8.7$ & - & $\begin{array}{l}\text { MBT is planned for one of } \\
\text { the clusters. Several options } \\
\text { have been considered. } \\
\text { Financial indication of } \\
\text { economic efficiency depends } \\
\text { on possibility to sell RDF or } \\
\text { compost like output. }\end{array}$ \\
\hline Volynska & - & - & - & - & - & $\begin{array}{l}\text { The need to create MBT } \\
\text { facilities is emphasized, but } \\
\text { the RWMP does not contain } \\
\text { any indicative indicators } \\
\text { (number of planned facilities, } \\
\text { their location, other } \\
\text { characteristics, etc.) }\end{array}$ \\
\hline $\begin{array}{l}\text { Dnipropetrovska } \\
\text { 1. Kamyanske } \\
\text { city }\end{array}$ & 122,000 & 37.9 & 311 & 22 & 47 & $\begin{array}{l}\text { For the five clusters MBT is } \\
\text { considered as an alternative } \\
\text { to the main scenario. }\end{array}$ \\
\hline $\begin{array}{l}\text { 2. Kryvyy } \\
\text { Rih city }\end{array}$ & 250,000 & 77.2 & 309 & 22 & 46 & $\begin{array}{l}\text { Therefore, the total number } \\
\text { of MBT may be higher }\end{array}$ \\
\hline $\begin{array}{l}\text { Ivano- } \\
\text { Frankivska/ } \\
\text { Ivano- } \\
\text { Frankivsk } \\
\text { city }\end{array}$ & $\begin{array}{c}130,000 \\
\text { with } \\
\text { possibilit } \\
\text { y of } \\
\text { increasin } \\
\text { g } \\
\text { capacity } \\
\text { till } \\
160,000\end{array}$ & 27.8 & 214 & 32 & 53 & $\begin{array}{l}\text { Planned outputs - recyclables } \\
(10 \%) \text { and SRF }\left(3^{\text {rd }} \text { class }\right) \\
(35 \%) \text {. Cement plant is near } \\
\text { the Ivano-Frankisk City. It is } \\
\text { estimated that the payback } \\
\text { period is about } 10 \text { years with } \\
\text { a tariff - } 1,500 \text { UAH/ton of } \\
\text { MSW. According to the } \\
\text { pessimistic scenario RDF } \\
\text { will be sold at a price of } 0,00 \\
\text { UAH. Upon receipt of } \\
\text { quality fuel of the } 1 \text { st and } \\
2 \text { nd class, it is possible to sell } \\
\text { fuel at the agreed price. }\end{array}$ \\
\hline Lvivska/Lviv & 240,000 & 35.0 & 146 & - & - & \\
\hline $\begin{array}{l}\text { Ternopilska/ } \\
\text { Skalat city }\end{array}$ & - & - & - & - & - & Biofermentation \\
\hline $\begin{array}{l}\text { Khmelnitska/ } \\
\text { Khmelnytsk } \\
\text { city }\end{array}$ & & & & & & $\begin{array}{l}\text { The cement Plant is in } \\
\text { Kamenets-Podilsky city. } \\
\text { MBT plant with SRF } \\
\text { production is considered. } \\
\text { Detailed calculation has not } \\
\text { been yet published. }\end{array}$ \\
\hline Chernihivska & & & & & & $\begin{array}{l}\text { For the Chernihiv region the } \\
\text { construction of the MBT } \\
\text { plant is impractical }\end{array}$ \\
\hline
\end{tabular}

* For most facilities the indicative assessment is given. Detailed figures will be clarified at the feasibility study stage

During the development of the National Strategy as one of the option the construction of mechanical biological waste treatment facilities in the settlements with population more than 400,000 people has been considered. But at final version the Strategy contains only reference on implementation of the pilot projects on alternative fuel production. 
It should be noted that in Ukraine there is no experience in construction mechanical biological waste treatment plants for MSW, there are only plants with anaerobic treatment (digestion) for agricultural waste (biogas plants). That is why assessments of possibilities of construction of mechanical biological waste treatment plants are approximate; their technical and economic characteristics are not presented in the Regional Waste Management Plans. It is planned to detail everything within feasibility study stage.

Also the methods of payment for solid recovered fuel / refuse derived fuel have not been taken into consideration - on what conditions the enterprises are ready to accept fuel. It will require the conclusion of contracts, coordination and research of calorific value of waste and fuel from waste, determination of supply volumes etc.

In addition, there are other barriers of an institutional, technical and economic nature. In particular: lack of reliable data on municipal solid waste generation, composition and management. Without accurate and up to date statistics it is difficult to plan accurately and thus difficult to operate the system effectively; low tariffs are not incentive to improve operational standards or to achieve increased levels of recycling. The relatively "low cost" of disposal creates distorted incentives for operators and local authorities in their choice between landfilling and recycling; lack of extended producer responsibility schemes; lack of capacity, particularly at local self-government level.

\section{Conclusions}

The waste management situation in Ukraine stays critical. Landfill is still the main and the cheapest option for treating municipal solid waste as results from lack of proper waste treatment infrastructure. Development and implementation Regional Waste Management Plans can give impetus to the development of municipal solid waste treatment infrastructure, in particular using mechanical biological waste treatment technologies. The mechanical biological waste treatment technology market is currently free and mechanical biological waste treatment with solid recovered fuel production for the cement industry is more realistic for the short term perspective.

There is a certain need for these technologies. Review Regional Waste Management Plans drafts showed that such typed of technologies are affordable for Ukrainians but cost recovery period is more than 8 years. There are many barriers that can scare away potential investors. Low rates of waste disposal tax and landfill gate fees make noncompetitive waste recovery technologies. Some risks related with necessity to take long term loans for initial investment as well as with necessity to have a guarantee for the stable feedstock of mixed waste. Lack of the experience in introducing such facilities in Ukraine may also be an obstacle too.

In order to accelerate the development of mechanical biological waste treatment technologies in Ukraine, it is necessary to raise tax rates on waste disposal, adopt a number of standards related to the system of measuring the quality of solid recovered fuel, enforce the system of environmental compliance monitoring as well as to carry out constant work with the population so that people pay for the provided municipal solid waste management services in a timely manner and in full. It is also necessary to take into account the following chains of refuse derived fuel and solid recovered fuel, i.e. bring the requirements to the system of monitoring air emissions in line with European requirements.

This work was conducted within the projects "Natural-technogenic and environmental safety in the conditions of economic transformations in Ukraine" (State registration No. 0116U007938) and "Environmental safety of agglomerations of the urborural type in the conditions of formation of the market of natural resources assets" (State registration No. 0118U005129). 


\section{References}

1. Khvesyk, M. Bystryakov, I., Obykhod, H. \& Khvesyk Yu. (2018). Assessment of the safety of environment in terms of sustainable development. Economic Annals-XXI, V. 170, Issue 3-4, 22-26. https://doi.org/10.21003/ea.V170-04

2. Ministry for Communities and Territories Development of Ukraine (2021). The state of the municipal waste management in Ukraine in 2020 Retrieved from: https://www.minregion.gov.ua

3. The Market for Mechanical Biological Waste Treatment in Europe. (n.d.). Ecoprog.com. https://www.ecoprog.com/publikationen/abfallwirtschaft/mba.htm

4. Den Boer, E., \& Jędrczak, A. (2017). Performance of mechanical biological treatment of residual municipal waste in Poland. E3S Web of Conferences, 22, 1-8. https://doi.org/10.1051/e3sconf/20172200020

5. Trullia, E., Ferronatob, N., Torrettab, V., Piscitellia, M., Masia, S., \& Mancinia, I. (2018). Sustainable mechanical biological treatment of solid waste in urbanized areas with low recycling rates. Waste Management, 71, 556-564. https://doi.org/10.1016/j.wasman.2017.10.018

6. Nasrullaha, M., Hurmea, M., Oinasa, P., Hannulab, J., \& Vainikkac, P. (2017). Influence of input waste feedstock on solid recovered fuel production in a mechanical treatment plant. Fuel Processing Technology, 163, 35-44. https://doi.org/10.1016/j.fuproc.2017.03.034

7. Jaspers Solid waste and Energy Division (2010). JASPERS, 2010: Staff Working Papers, Mechanical Biological Treatment Plants, Jonas Byström. http://www.jaspersnetwork.org

8. Kinash, I., Shtogryn, H., Sakal, O., Zapukhliak, I. (2019). The ecologization of housing and communal services of Ukraine in the context of sustainable development. Journal of Eastern European and Central Asian Research, 6(1), 113-130. https://doi.org/10.15549/jeecar.v6i1.251

9. Mikhno, I., Koval, V., Shvets, G., Garmatiuk, O., \& Tamošiūnienè, R. (2021). Green Economy in Sustainable Development and Improvement of Resource Efficiency. Central European Business Review, 10(1), 99-113. https://doi.org/10.18267/j.cebr.252

10. Vinnytska Regional State Administration (2020). Draft of the Regional Waste Management Plans of the Vinnytska oblast until 2030. http://vin.gov.ua/

11. Volynska Regional State Administration (2020). Draft of the Regional Waste Management Plans of the Volynska oblast until 2030. https://voladm.gov.ua

12. Dnipropetrovska Regional State Administration (2020). Draft of the Regional Waste Management Plans of the Dnipropetrovska oblast until 2030. https://oblrada.dp.gov.ua

13. Ivano-Frankivsk Regional State Administration (2020). Draft of the Regional Waste Management Plans of the Ivano-Frankivska oblast until 2030. http://www.if.gov.ua/files/uploads/plan\%20seo.pdf

14. Ternopilska Regional State Administration (2020). Draft of the Regional Waste Management Plans of the Ternopilska oblast until 2030. http://ecoternopil.gov.ua/images/Programa_ONPS/Reg_plan2030.pdf

15. Khmelnytska Regional State Administration (2020). Draft of the Regional Waste Management Plans of the Khmelnytska oblast until 2030. https://www.adm-km.gov.ua

16. Chernihivska Regional State Administration (2020). Draft of the Regional Waste Management Plans of the Chernihivska oblast until 2030. https://apk.cg.gov.ua 